\title{
IMPLEMENTASI TEKNIK SELF CONTROL UNTUK MENGURANGI KECANDUAN GAME ONLINE PADA PESERTA DIDIK DI MASA PANDEMI COVID-19
}

\author{
Eva Yuanita Ferdian, S.Pd. \\ SMK Negeri 2 Bagor Nganjuk \\ agvaaflah09@gmail.com \\ Fitriana Dyah Wulandari, S.Pd. \\ SMK Raden Patah Kota Mojokerto \\ fitrididik2011@gmail.com
}

\begin{abstract}
Abstrak
Sebagian besar peserta didik pada saat pandemi covid-19 mengalami kebosanan dengan situasi yang belum normal, oleh sebab itu salah satu dampak dari kebosanan peserta didik dalam melakukan pembelajaran daring yakni dengan bermain game online, permainan game online meningkat penggunaannya ketika di masa pandemi covid-19. Ada perbedaan yang signifikan dari jumlah pengguna game online antara sebelum dan pada saat pandemi covid-19, waktu lama bermain pengguna game online juga mengalami peningkatan signifikan yakni sebesar 47 persen. Kondisi mental pada anak/peserta didik rata-rata masih labil sehingga mudah lepas kontrol ketika sedang asyik dengan bermain game online, Untuk menangani masalah kecanduan game online peserta didik agar tidak berkelanjutan, maka perlu diberikan suatu teknik untuk membimbing peserta didik dalam upaya mengurangi tingkat kecanduan game online. Dengan diberikannya suatu teknik pengubahan perilaku, maka peserta didik dapat mengontrol dan mengarahkan perilakunya ke arah asertif yang lebih positif. Pemilihan teknik yang berfungsi untuk mengubah perilaku dapat digunakan pendekatan kognitif behavior. Salah satu teknik yang digunakan adalah teknik self control. Guru bimbingan Konseling bisa mengimplementasikan self control untuk mengurangi kecanduan game online pada peserta didiknya di masa pandemi covid-19 ini dengan menggunakan metode konseling daring
\end{abstract}

Kata Kunci: Self Control, Kecanduan Game Online.

\begin{abstract}
Most students at the time of the covid-19 pandemic experienced boredom with situations that were not yet normal, therefore one of the impacts of students' boredom in doing online learning is by playing online games, online game use has increased during the Covid-19 pandemic. . There is a significant difference in the number of online game users between before and during the Covid-19 pandemic, the length of time playing online game users has also increased significantly, namely by 47 percent. The mental condition of children / students on average is still unstable so it is easy to lose control when they are engrossed in playing online games. To deal with the problem of online game addiction of students so that it is not sustainable, it is necessary to provide a technique to guide students in an effort to reduce addiction levels online game. By providing a behavior change technique, students can control and direct their behavior towards a more positive assertiveness. Selection of techniques that function to change behavior can be used a cognitive behavior approach. One of the techniques used is the self-control technique. Covid-19 guidance teachers can implement self-control to reduce addiction to online games in their students during the Covid-19 pandemic by using online counseling methods.
\end{abstract}

Keywords: Self Control, Online Game Addiction.

\section{PENDAHULUAN}

Pandemi Covid-19 merupakan situasi baru yang dihadapi seluruh dunia, termasuk bangsa Indonesia mau tidak mau dan siap tidak siap pemerintah dan masyarakatnya harus menghadapi tersebut. Oleh sebab itu, pemerintah dan masyarakat Indonesia harus mempersiapkan paradigma baru dalam berpikir dan bertindak, dahulu sebelum pandemi covid-19 kita bebas kemanapun, dengan leluasa berinteraksi tanpa jarak (social distance), pembelajaran di sekolah pun berjalan sesuai koridor kurikulum, namun semua itu harus dirubah dalam masa pandemi covid-19 ini.

Pembelajarn jarak jauh dengan sistem daring merupakan hal baru bagi kebanyakan peserta didik dan tenaga pendidik begitu pula intensitas penggunaan gawai melonjak tinggi (DINA, 2020). Sebab aktifitas kebanyakan 
dirumah dan peserta didik terbatasi kegiatannya sehingga memicu kegiatan lain yang bisa menghibur dirinya dari kebosanan pembelajaran jarak jauh sistem daring tersebut.

Sebagian besar peserta didik pada saat pandemi covid19 mengalami kebosanan dengan situasi yang belum normal, oleh sebab itu salah satu dampak dari kebosanan peserta didik dalam melakukan pembelajaran daring yakni dengan bermain game online, permainan game online meningkat penggunaannya ketika di masa pandemi covid19. Sesuai dengan informasi di berita online, Okezone.com menyebutkan; main game online lebih digeluti di masa pandemi. Hyper-Casual Gaming dari Adjust merilis laporannya masyarakat mendownload aplikasi game online di handphone pada akhir Maret 2020 beberapa minggu setelah status pandemi ditetapkan oleh pemerintah sudah mengalami peningkatan sebesar 75 persen dibanding akhir Maret 2019. Ada prebedaan yang signifikan dari jumlah pengguna game online antara sebelum dan pada saat pandemi covid-19 saat ini, waktu lama bermain pengguna game online juga mengalami peningkatan signifikan yakni sebesar 47 persen.

Situasi dan kondisi seperti ini yang memicu anak-anak terpaku dengan gawainya dan pembelajaran jarak jauh sistem daring juga sedikit banyak menjadi anak untuk tertarik dengan permainan game online. Hal tersebut yang membikin orang tua resah selama pembelajaran jarak jauh sistem daring. Tetaapi mereka tidak punya pilihan lain sebab keberadaan gawai sangat penting untuk membantu pembelajaran anak dan komunikasi peserta didik dengan tenaga pendidik, rata-rata peserta didik tiap kelas memiliki lebih dari tiga group whatsapp untuk menunjang pembelajaran daringnya. Biasanya beda mata pelajaran dan beda guru beda pula group whatsappnya, oleh sebab itu keberadaan gawai di tangan anak sangatlah penting orang tua kesulitan juga untuk memantau aktifitas si anak dalam penggunaan gawai tersebut, anak-anak juga butuh 'teman' pengganti untuk membunuh waktu--di luar jam belajar yang juga online tersebut salahsatunya bermain game online.

Hal yang wajar jika orang tua memiliki keresahan yang tinggi terhadap anaknya karena di balik meningkatnya aktivitas game online itu, ada ancaman yang mengintai bernama Gaming Disorder yang dapat memicu kesehatan psikis. Organisasi Kesehatan Dunia (WHO) mendaftarkan kondisi ini ke dalam daftar klasifikasi penyakit internasional (ICD) edisi ke-11 sejak pertengahan 2018 lalu. Di Indonesia sendiri sudah muncul beberapa kasus anak yang kecanduan permainan game online. Beberapa kasus kematian yang berhubungan dengan game online bahkan telah beberapa kali dilaporkan. Seorang anak laki-laki berusia 13 tahun di India, misalnya, mengakhiri hidupnya sendiri setelah sang ayah memintanya berhenti bermain game berjenis Battle Royale pada Juli lalu.

Kasus game online maut juga dicatat di negara yang merupakan pasar smartphone kedua terbesar di dunia itu pada Januari lalu. Seorang pria berusia 25 tahun meninggal akibat stroke otak setelah bermain game berhari-hari. Kondisi mental pada anak/ peserta didik rata-rata masih labil sehingga mudah lepas kontrol ketika sedang asyik dengan bermain game online, Untuk menangani masalah kecanduan game online peserta didik agar tidak berkelanjutan, maka perlu diberikan suatu teknik untuk membimbing peserta didik dalam upaya mengurangi tingkat kecanduan game online. Dengan diberikannya suatu teknik pengubahan perilaku, maka peserta didik dapat mengontrol dan mengarahkan perilakunya ke arah asertif yang lebih positif. Sehingga memberikan dampak yang positif pula bagi kondisi mental peserta didik. Pemilihan teknik yang berfungsi untuk mengubah perilaku dapat digunakan pendekatan kognitif behavior. Salah satu teknik yang digunakan adalah teknik self control.

Berikut beberapa faktor yang mengakibatkan peserta didik kecanduan game online, faktor internal, yaitu; (a) Rasa bosan yang dirasakan peserta didik ketika lama berada di rumah (b) lingkungan teman sebaya yang sudah melakukan game online, (c) Keinginan yang kuat dari diri peserta didik untuk memperoleh skor tinggi dalam game online (Sumarmo, 2004), (d) Ketidakmampuan mengatur prioritas untuk mengerjakan aktivitas penting lainnya (Masya \& Candra, 2016) 
(e) Kurangnya self control dalam diri remaja, sehingga remaja kurang mampu mengantisipasi dampak negatif yang timbul pada dirinya dari bermain game online secara jangka waktu yang lama. Faktor eksternal yang menyebabkan terjadinya peserta didik kecanduan bermain game online yaitu (a) Lingkungan keluarga yang kurang terkontrol, hal ini perhatian orang tua/saudara peerta didik sangat berperan dalam pengendalian waktu bermain game online (b) Keterbatasan hubungan sosial di rumah, sehingga peserta didik memilih alternatif bermain game sebagai aktivitas yang mengisi hari-harinya selama di rumah (c) keinginan orang tua yang tinggi terhadap anaknya untuk mengikuti pembelajaran jarak jauh atau tuntutan tugas daring dari bapak/ibu guru yang tinggi, sehingga kebutuhan primer anak, seperti kebersamaan dengan teman sebaya, bermain dengan keluarga menjadi terlupakan.

Di antara faktor-faktor penyebab kecanduan game online tersebut, yang dijadikan fokus penulis pada artikel ini adalah kurangnya self control dalam diri peserta didik, sehingga peserta didik kurang bisa mengendalikan dampak negatif yang timbul dari bermain game online secara berlebihan.

Menurut Fox \& Calkins (dalam Novianti, 2014), kontrol diri merupakan kapasitas dalam "self", yang dapat digunakan untuk mengontrol variabel - variabel luar yang menentukan tingkah laku. Sedangkan teknik kontrol diri di sini merupakan suatu usaha atau prosedur yang akan dijalankan untuk mengarahkan dan mengontrol perilaku. Di mana nantinya subjek akan terlibat dalam beberapa atau keseluruhan prosedur treatmen untuk mencapai tujuan yang diinginkan (Baumeister, Vohs \& Tice, 2007)

\section{METODE}

Jenis penelitian ini adalah penelitan kepustakaan (library research), yaitu serangkaian penelitian yang berkenaan dengan metode pengumpulan data pustaka, atau penelitian yang obyek penelitiannya digali melalui beragam informasi kepustakaan. Data yang digunakan dalam penelitian ini adalah data sekunder. Metode pengumpulan data yang digunakan dalam penelitian ini adalah metode dokumentasi. Metode dokumentasi merupakan metode pengumpulan data dengan mencari atau menggali data dari literatur yang terkait dengan apa yang dimaksudkan dalam rumusan masalah. Analisis data yang digunakan dalam penelitian ini adalah analisis anotasi bibliografi (annotated bibliography). Anotasi berarti suatu kesimpulan sederhana dari suatu artikel, buku, jurnal, atau beberapa sumber tulisan yang lain, sedangkan bibliografi diartikan sebagai suatu daftar sumber dari suatu topik.

\section{HASIL DAN PEMBAHASAN}

\section{A. Karateristik Kecanduan Game Online}

Game online adalah permainan yang menggunakan komputer atau gawai dengan melibatkan jaringan internet untuk bermain dan menghubungkan antar pemain. Fitur game online bersifat menghibur dan mengurangi tekanakan, kebosanan serta mengurangi tuntutan pembelajaran atau tugas sekolah. Ada tiga macam jenis permainan game online antara lain; (a) Fisrst Person Shooter (FPS) yaitu jenis permainan menggunakan sudut pandang orang pertama yang menampilkan secara persis sesuai dengan yang dilihat oleh mata karakter yang di mainkan. Contohnya penggunaan tembak, pisau, dsb. (2) Role Playing Game (RPG) yaitu permainan yang memiliki ciri dimana sesorang diberi kebebasan untuk mengembangkan karakter permainnya dan membutuhkan waktu yang panjang dalam permainan ini untuk mencapai level yang tinggi. (3) Massively Multiplayer Online Role Playing Game (MMORPG) yaitu permainan online dengan ciri permainan dilakukan berkelompok atau bekerja sama untuk menuntaskan misi di dalam dunia maya. Permainan Game online ini yang paling diminati peserta didik sebab bisa interaksi dengan temannya maupun orang lain.

Peserta didik yang mengalami kecanduan game online memiliki 9 kriteria, antara lain; (a) game online menjadikan aktifitas paling dominan dalam kesehariannya, (b) menarik diri dari lingkungan sekitar, ia lebih nyaman dengan gawainya, (c) intoleransi/ waktunya di fokuskan untuk bermain game online, (d) Kehilangan mood untuk sosialisasi dengan teman (bermain dengan teman sebaya), 
(e) Gagal mengontrol diri/sulit mengendalikan diri, (f) cenderung berbohong untuk menutupi kegemaran bermain game online $(\mathrm{g})$ penggunaan game online yang terus menerus tidak memperhatikan batas waktu (h) sulit berkonsentrasi dalam hal pembelajaran/mengerjakan tugas sekolah (i) menggunakan game online untuk pelampiasan atau pembebasan suasana hati yang kalut, bosan dsb.

Kecanduan permainan game online dalam pandemi saat ini tidak terlepas dari peran orang tua dan anggota keluarga karena waktu terlama peserta didik cenderung di dalam rumah. Sehingga guru kesulitan mengontrol aktifitas peserta didiknya. Peserta didik yang sudah mengalami kecanduan akan menjadikan game online sebagai pemuas hati dalam memenuhi kebutuhan soaialnya, sebab game online akan menjadi pengganti kepuasan akan kebutuhan realsi di dalam dunia nyata

\section{B. Implementasi Teknik Self Control}

Setiap orang terutama pada usia peserta didik tentunya ingin memiliki rasa kebebasan yang tinggi untuk mengaktualisasikan diri, namun dalam masa pandemi saat ini semua aktifitas cenderung terbatasi semua dilakukan dalam rumah untuk menjaga diri dari serangan covid 19. Setiap kebebasan atau aktualisasi diri membutuhkan sebuah regulasi atau dorongan dalam melakukan tindakan dengan spontan. Self control atau kontrol diri memang sebuah strategi yang bisa dilakukan guru bimbingan konseling kepada peserta didiknya maupun terkecuali orang tua kepada anaknya. Dalam hal ini ada juga penerapan efek-efek psikologis yang bisa mengarah ke arah positif maupun negatif untuk dapat mempengaruhi kontrol diri terhadap munculnya sebuah tingkah laku yang bisa dikatakan cukup besar dan berdampak pada kehidupan kesehariannya. Berikut konsep Implementasi Self control untuk mengurangi kecanduan game online pada peserta didik di masa pandemi covid-19;

1. Memberikan tujuan yang konkrit mengenai arah tujuan

Self control bertujuan untuk memahami mengenai halhal yang mengarah pada modifikasi perilaku, perubahan sikap yang ke arah lebih asertif dan bertangung jawab, oleh sebab itu hal utama yaitu memahami terlebih dahulu perilaku negatif konseli tersebut.

\section{Mampu menghadapi berbagai situasi}

Dalam hal ini kita dapat melihat seberapa besar kekuatan seseorang dalam menghadapi situasi dan kondisi yang dialaminya sendiri. Penerapan self control mampu memberikan paparan mengenai hal-hal yang berkaitan dengan situasi kondisi yang dapat membuatnya mengarah ke kondisi dan situasi yang lebih rileks atau sebaliknya malah tidak bisa membuat dirinya rileks, gugup, cemas dsb.

\section{Menumbuhkan rasa percaya diri}

Dalam Implementasi self control hal yang paling penting adalah bagaimana cara peserta didik/konseli memberi kepercayaan pada dirinya sendiri, hal ini juga bisa dikaitkan dengan tingkat rasa percaya diri konseli ketika dapat paksaan atau dipaksa oleh orang lain untuk melakukan sesuatu. Hal ini sangat mempengaruhi hasil yang berdampak pada psikologis konseli.

4. Memberikan stimulus pengubahan pola perilaku

Dalam hal ini pemberian stimulus positif merupakan cara untuk menjadikan konseli menjadi pribadi yang lebih baik lagi. Dengan dorongan pengubahan perilaku secara tidak langsung bisa kita lihat berbagai perubahan yang muncul mulai dari kekuatan dasar mental juga perubahan sikap yang lebih baik lagi, sehingga berdampak pada aspek psikologi yang dilakukan konseli bisa dikaitkan dengan kehidupan asertif kesehariannya

5. Mengajarkan cara mengatasi frustasi dan ledakan emosi Jika konseli dapat mengontrol dirinya sendiri dari rasa frustasi juga mengontrol emosi dalam dirinya tentu bisa dikatakan ia memiliki self control yang baik, tindakan ini dilakukan untuk menjadikan penguat memberikan sesuatu yang positif pada dirinya, sehingga ia bisa dengan mudah mengontrol dan menghadi berbagai situasi kondisi yang muncul pada dirinya sendiri.

6. Mampu menunda kesenangan dirinya sendiri

Penerapan self control pada peserta didik/konseli bisa kita lihat dari cara ia menunda kesenangan atau kepuasan pada dirinya. Dengan mengatur perilaku yang terjadi. Cara ini bisa minta bantuan kepada orang terdekat untuk saling mengingatkan sehingga dengan kemampuan menunda kesenangan untuk dirinya bisa dikatakan self control yang ada dirinya berjalan efektif 
7. Memberikan stimulus pengubahan pola berpikir

Self control bisa diterapkan dengan memberikan berbagai ransangan dengan pengubahan pola pikir yang lebih positif, memang hasilnya tidak langsung muncul namun dengan pemberian ransangan tersebut harapannya bisa mengubah cara berperilaku sehari-hari.

8. Menumbuhkan inisiatif yang tinggi untuk dirinya

Penerapan self control berikutnya yakni dengan melihat cara konseli yang mampu membuat sebuah inisiatif untuk dirinya sendiri, terlihat sepintas cara ini sangat mudah namun untuk mengawalinya membutuhkan perhatian khusus yang tidak mudah, khususnya dalam pencarian solusi dari setiap masalah. Inisistif muncul dari diri sendiri lebih efektif dalam pemecahan masalah.

9. Implementasi self control disesuaikan dengan usia

Penerapan self control yang baik salah satunya memperhatikan usia atau kematangan usia, sebab ketika dalam memodifikasi perilaku yang baik harus memperhatikan sisi usia konseli tersebut sehingga bisa mampu mengidentifikasi dan mengubah pola pikir serta dapat fokus pada tujuannya. Berbeda jika usia konseli masih terlalu kecil kategori anak-anak yang mengidentifikasi pikiran saja terkadang kesulitan.

10. Mampu mengontrol keputusan pribadi

Salah satu cara yang dapat dilakukan ketika mengontrol keputusan yakni dengan bantuan orang lain yang mampu melakukan sebuah tindakan, seperti halnya bantuan kakak konseli untuk membantu memantau dan mengontrol perilaku atau keuptusan yang di ambil oleh konseli itu sendiri.

11. Mampu mengantispasi keadaan dengan baik

Penerapan selanjutnya yaitu mengantisipasi keadaan dengan baik, hal ini bisa kita cermati dari kemampuan konseli dalam mengantispasi keadaannya, dengan cara ini kita bisa melihat keberhasilan konseli menerapkan self controling pada dirinya dengan baik

12. Memberikan reward pada diri sendiri

Reward untuk diri sendiri sangatlah baik untuk memperkuat kepercayaan diri serta menghargai pada hasil usaha sendiri adalah hal yang sangat positif, hal ini bisa di jadikan acuan perkembangan dalam sebuah proses penetapan penilaian konseli kepada orang lain

\section{Implementasi Teknik Self Control di Masa Pandemi Covid-19}

Virus corona atau biasa di sebut covid-19 menyebabkan perubahan tatanan, sistem dalam pembelajaran termasuk dalam layanan bimbingan dan konseling di sekolah, selama pembelajaran jarak jauh sitem daring, pertemuan untuk konseling menurun drastis, hal itu tidak menutup kemungkinan guru bimbngan konseling berinovasi untuk melakukan konseling daring, begitu juga ketika guru bimbingan konseling mendapati peserta didiknya mengalami kecanduan online, maka hal yang perlu dipersiapkan oleh guru bimbingan konseling yakni media konseling itu sendiri, tentunya implementasi teknik Self Control di masa pandemi covid-19 ini bisa saja terjadi dimanapun dan kapanpun, oleh sebab itu penulis melalui kajian literatur mencoba menulis artikel ini untuk digunakan sebagai bahan refrensi oleh guru bimbingan konseling yang lainnya.

Ketika guru bimbingan dan konseling mendapati siswanya kecanduan game online pada saat pandemi saat ini, mungkin bisa dilakukan konseling daring melalui video call whatsapp ataupun aplikasi lainnya dengan metode implementasi Teknik Self control dengan perincian langkah-langkah seperti di atas. Begitupula komunikasi dengan orang tua peserta didik. Konseling daring sangat efektif dan tergantung bagaimana cara guru bimbingan konseling berkomunikasi dengan konseli melalui vido call tersebut tentunya, konseling daring tidak sebebas dengan konseling offline, karena tanpa kendala jaringan internet. Konseling daring juga memerlukan kualitas jaringan intert yang baik untuk penunjang keberlangsungan komunikasi guru bimbingan dan konseli. Dari segi waktu lebih fleksibel konseling daring, sebab bisa di lakukan kapanpun, darimanapun sehingga jarak bukan lagi alasan untuk tidak membantu penyeleseian masalah peserta didik. Guru bimbingan konseling di masa pandemi covid-19 saat ini tetap memberikan layan konseling terbaiknya kepada peserta didiknya khusunya dengan strategi-strategi khusus untuk penanganan permasalahan siswa. 


\section{PENUTUP}

\section{Simpulan}

Perbedaan yang signifikan dari jumlah pengguna game online antara sebelum dan pada saat pandemi covid19, menunjukkan peserta didik lebih cenderung bermain game online daripada aktifitas lainnya, waktu lama bermain pengguna game online juga mengalami peningkatan signifikan yakni sebesar 47 persen. Kondisi mental pada anak/peserta didik rata-rata masih labil sehingga mudah lepas kontrol, lupa waktu ketika sedang asyik dengan bermain game online. Dengan diberikannya suatu teknik pengubahan perilaku, maka peserta didik dapat mengontrol dan mengarahkan perilakunya ke arah asertif yang lebih positif.

Pemilihan teknik yang berfungsi untuk mengubah perilaku dapat digunakan pendekatan kognitif behavior. Salah satu teknik yang digunakan adalah teknik self control.. Adapun konsep Implementasi Self control untuk mengurangi kecanduan game online pada peserta didik di masa pandemi covid-19 anatara lain; (1) Memberikan tujuan yang konkrit mengenai arah tujuan, (2) Mampu menghadapi berbagai situasi, (3) Menumbuhkan rasa percaya diri, (4) Memberikan stimulus pengubahan pola perilaku, (5) Mengajarkan cara mengatasi frustasi dan ledakan emosi (6) Mampu menunda kesenangan dirinya sendiri (7) Memberikan stimulus pengubahan pola berpikir (8) Menumbuhkan inisiatif yang tinggi untuk dirinya (9) Implementasi self control disesuaikan dengan usia (10) Mampu mengontrol keputusan pribadi (11) Mampu mengantispasi keadaan dengan baik (12) Memberikan reward pada diri sendiri

\section{Saran}

Selama pembelajaran jarak jauh sistem daring, pertemuan untuk konseling menurun drastis, hal itu tidak menutup kemungkinan guru bimbingan konseling berinovasi untuk melakukan konseling daring, maka hal yang perlu dipersiapkan oleh guru bimbingan konseling yakni media konseling itu sendiri,bisa melalui video call whatsapp, chat whatsapp, facebook, aplikasi zoom dsb. tentunya implementasi teknik Self Control di masa pandemi covid-19 ini bisa saja terjadi dimanapun dan kapanpun menyesuaikan kondisi yang ada.

\section{DAFTAR PUSTAKA}

Asta, Derina. 2008. 12 Penerapan Self Control dalam Modifikasi Perilaku. Tersedia: https://dosenpsikologi.com/ di akses tanggal 29 Oktober 2020

Damayanti, Nurlaela. 2019. Pengaruh Penerapan Teknik Self Control Untuk Mengurangi Perilaku Bullying Pada Siswa Tunalaras di SLB Prayuwana Yogyakarta. Jassi Anakku Vol. 2. di akses tanggal 30 Oktober 2020

Fajria, Hilda. 2020. Main Game Online Lebih Digeluti di Masa Pandemi, Awas Kecanduan. Tersedia: https://lifestyle.okezone.com/read/2020/08/29/6 2/2269359. di akses tanggal 29 Oktober 2020

Hartik, Andi. 2020. Dihina karena Kalah Main Game Online, Remaja Ini Bunuh Rekan Kerjanya. Tersedia:https://regional.kompas.com/read/2020/ 09/09/20065321. di akses tanggal 29 Oktober 2020

Hapsari, Ayu Dyah. (2009). Hubungan antara Social Interest dengan Self Control pada Remaja Pelaku Index Offenses di Lembaga Pemasyarakatan Anak Blitar. Skripsi. Program Studi Psikologi, Jurusan Bimbingan Konseling dan Psikologi, Fakultas Ilmu Pendidikan, Universitas Negeri Malang. Tidak Diterbitkan.

Sholikah Putri Agus. Purwoko, Budi. 2016. Penerapan Teknik Self Control Untuk Mengurangi Kecanduan Game Online Siswa Kelas XI Smk Negeri 1 Driyorejo. Tersedia: https://www.neliti.com/id/publications/252401/ di akses tanggal 29 Oktober 2020

Safitri, Ika Dwi. Christiana Elisabeth. 2016. Penerapan Teknk Self-Control Untuk Mengurangi Perilaku Off Task Siswa Kelas VIII di SMPN 1 Lengkong Nganjuk.Tersedia: 
Jurnal Bikotetik (Bimbingan dan Konseling : Teori dan Praktik) Volume 05 Nomor 01 Tahun 2021, 1-48

https://www.neliti.com/id/publications/252304/

di akses tanggal 29 Oktober 2020

DINA, I. S. (2020). PROSES PEMBELAJARAN PADA MASA COVID-19 (TANTANGAN DAN SOLUSI). Minda Mahasiswa Indonesia: Kenali Industri 4.0 Hadapi COVID-19, 61.

Masya, H., \& Candra, D. A. (2016). Faktor-faktor yang mempengaruhi perilaku gangguan kecanduan game online pada peserta didik kelas $\mathrm{x}$ di madrasah aliyah al furqon prabumulih tahun pelajaran 2015/2016. KONSELI: Jurnal Bimbingan Dan Konseling (E-Journal), 3(2), 103-118.

Sumarmo, U. (2004). Kemandirian belajar: apa, mengapa, dan bagaimana dikembangkan pada peserta didik.

Makalah Pada Seminar Tingkat Nasional. FPMIPA UNY Yogyakarta Tanggal, 8. 